\title{
Instrumentation and Computer Interface Design for Forward Extrusion Tool
}

\author{
P. Tiernan*, ${ }^{, 1}$ and B. Draganescu ${ }^{2}$ \\ ${ }^{I}$ Materials and Surface Science Institute, University of Limerick, Limerick, Ireland \\ ${ }^{2}$ Dept. of Manufacturing and Operations Engineering, University of Limerick, Limerick, Ireland
}

\begin{abstract}
This paper describes the instrumentation and computer interface design for an extrusion tool to monitor certain process parameters during forward cold extrusion. A load sensing component, i.e. load cell was designed and manufactured to measure the extrusion forces. The load cell consisted of an individual component within a die set mounted in a 200-tonne hydraulic press, designed to study forward extrusion of aluminum alloys. The extrusion load measurement is based upon a number of strain gauges bonded to the central section of the component. The extrusion force was transmitted through a pressure plate to the load sensing component. A linear variable differential transformer (LVDT) was used to provide an output on the punch linear travel during the extrusion process. Both the load cell and the LVDT were calibrated and a complete programme of cold extrusion of aluminum was carried out to validate the setup. The extrusion process was monitored using personal computer (PC) running LabVIEW software.
\end{abstract}

\section{INTRODUCTION}

Much of the research in metal forming operations has focused on experimental studies of die wear and life. By minimising the load and energy used in the extrusion process, die life is maximised and die wear is maintained at a minimum [1]. Various researchers have attempted to estimate the energy consumed in the extrusion processes by means of modelling approaches [ $2 \& 3]$. Other researchers have combined theoretical and experimental studies of friction in metal forming [ $4 \& 5$ ]. In metal forming experimentation, determination of the forming loads is critical to the success of the process. The force required for forming has consequences in the design of tooling and fixtures, and also for the machinery used [6]. Various methods of measuring the forming loads during processing have been proposed [7-9]. In cold extrusion, which is used for the manufacture of special sections and hollow articles, the material is generally made to flow in the cold condition by the application of high pressure. The high pressures force the material through a cavity enclosed between a punch and a die. Cold extrusion can be used with any material that possesses adequate cold workability - e.g., tin, zinc, copper and its alloys, aluminium and its alloys. Indeed it is for these metals that the process is more widely adopted. Low-carbon soft annealed steel can also be cold extruded. If the product cannot be fully shaped in a single operation, the extrusion process may be performed in several stages [10]. The relationship between extrusion velocity with both temperature distribution within the extruded part and extrusion load has been investigated by a number of researchers [11-15]. The extrusion load was shown to increase with extrusion velocity. The magnitude of the increase is larger at higher reduction ratios.

*Address correspondence to this author at the Materials and Surface Science Institute, University of Limerick, Limerick, Ireland; Tel: +353 61213503 ; Fax: +353 61 202913; E-mail: peter.tiernan@ul.ie
In the current work, as part of an experimental programme of research on the cold extrusion of aluminum, a complete die set was designed and manufactured for an experimental programme. It consisted mainly, of three main plates; upper, active and lower. The upper and active plates were free to move on four pillars. A rapid punch and die release system was incorporated into the overall tool design to facilitate reduced experiment set up times and allow a high degree of experimental flexibility. A 3D exploded solid model and photograph of the die set is presented in Figs. (1 and 2) respectively. The die included an extrusion forcesensing component to allow determination of forming loads up to a maximum of $2000 \mathrm{kN}$. The load cell was machined from a single piece of high-strength steel with a minimum yield stress of $1200 \mathrm{MPa}$. Strain gauges were bonded to the upper and lower surfaces of the hollowed section. The extrusion force was transmitted to the load sensing component through a pressure plate. A hemispherical profile on the contact surface of the load cell eliminated any forces present in the horizontal plane.

The current research is of great significance as acquiring the experimental data is a major step in the application of the Response Surface Method (RSM) which will be carried out at a later stage of the current research programme. The RSM technique considers the correlation between certain process parameters and the obtained results as surfaces in the dimensional space of the variables [16]. The classical research methodology still commonly used consists of varying one process parameter while the levels of the other parameters are kept constant. It becomes obvious that, when analysing a large number of independent process variables, the method is very time consuming. With the RSM technique, during the experimental programme the analysed process variables are simultaneously assigned a limited number of values within a specific range. This allows the identification and quantification of the interaction between the chosen variables, thus contributing to a more precise determination of the global 
optimum. To determine both the RSM model adequacy and accuracy, it was necessary to experimentally determine extrusion forces for a number of experiments. As maximum extrusion forces of approximately $2000 \mathrm{kN}$ were expected, the procurement of a suitable off-the-shelf load measuring device was economically prohibitive. Hence, it was decided to design and manufacture a suitable low-cost load cell within the research facility.

\section{LOAD CELL DESIGN}

In order to provide maximum accuracy and signal output, a full Wheatstone bridge circuit, containing three strain gauges on each branch arm was chosen as shown in Fig. (3).

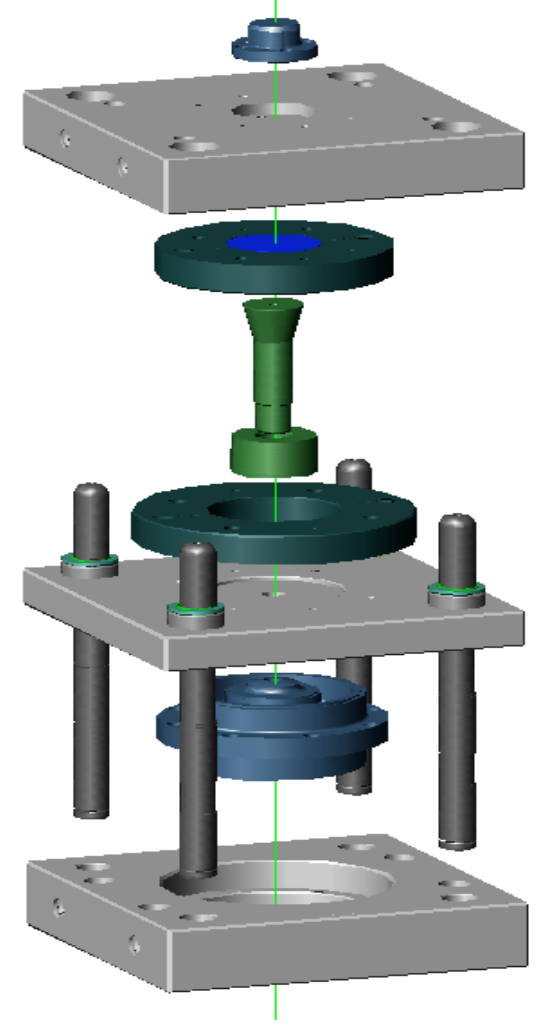

Fig. (1). Exploded view of die set.

Based on the Wheatstone bridge principle, the strain gauges forming arms (1) and (3) were mounted on surfaces subjected to compression while the strain gauges forming arms (2) and (4) were mounted on a surface subjected to tension. The optimal position for mounting the strain gauges was established using an ANSYS (Ver.6.0) finite element (FE) model of the load-sensing component as shown in Fig. (4). The complete load cell design is presented in Fig. (5).

The elastic deformation of the load cell induced by the maximum extrusion load was determined from the input of appropriate geometry, material properties and boundary conditions. The meshed axisymmetrical FE load cell model, consisting of 1355 PLANE 82 elements, is presented in Fig. (6). Material properties associated with the model were that of high-strength spring steel. Values of Young's Modulus, E and Yield Strength, $S_{\mathrm{y}}$ of $215 \mathrm{GPa}$ and $1200 \mathrm{MPa}$ respectively were assigned to the load cell material for the FE model. As shown in Fig. (6), boundary conditions were assigned to the

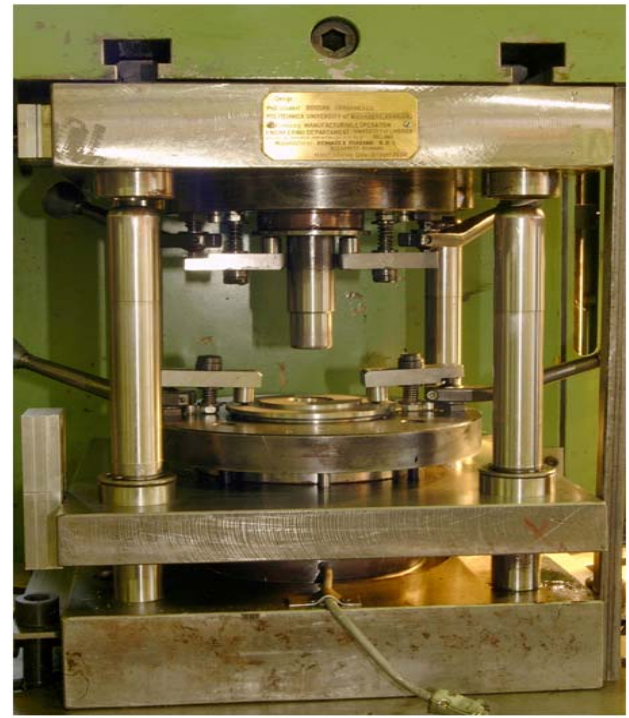

Fig. (2). Assembled extrusion tool.

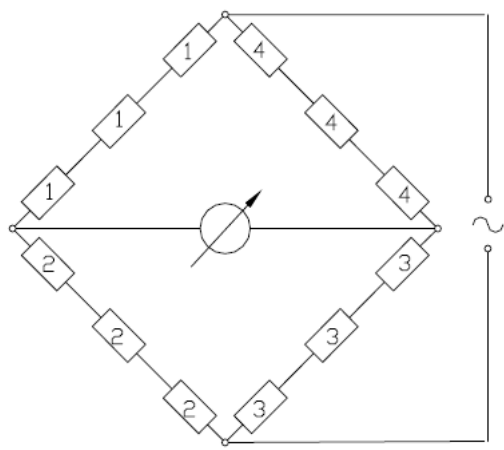

Fig. (3). Strain gauge configuration.

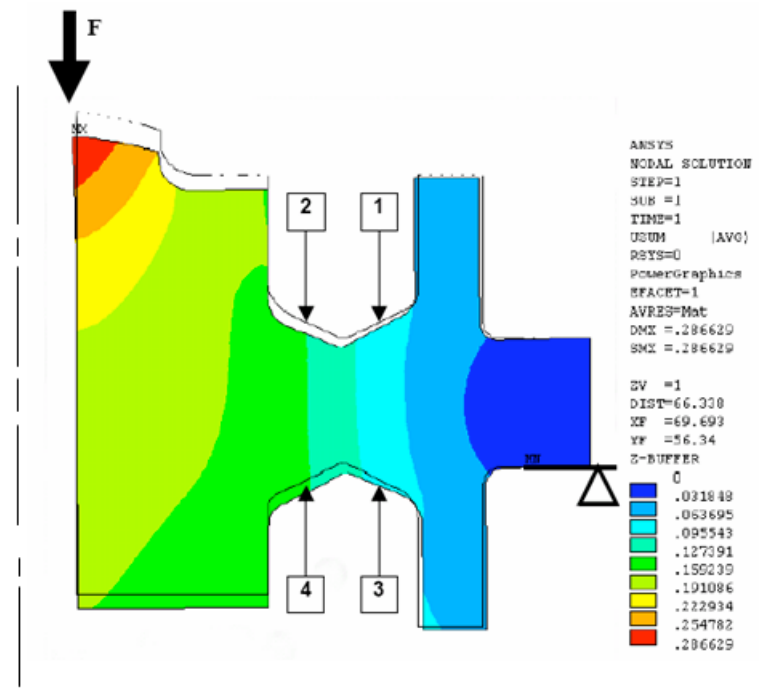

Fig. (4). Strain gauge positions shown on axisymmetric FE load cell model.

model to fix it in the $\mathrm{X}, \mathrm{Y}$ and $\mathrm{Z}$ directions at its centre section. Due to its working principle, the strain gauge output is a measure of the average strain recorded over the surface covered by the gauge grid. Also, strain limitations required 
that the deformation of the gauge grid was limited to $3 \%$. Therefore, choice of the optimal position of the strain gauge on the load cell surface was vital for an accurate and realistic reading of the forming load. The design of the load cell provided adequate mounting locations for the positioning of the strain gauges. It is evident that an area of almost linear strain variation is obtained on the analysed surfaces as shown in Fig. (4). This feature provides an accurate and realistic variation of the strain gauges resistance with the elastic deformation of the load cell. The geometry of the surface where linear strain variation occurs allowed the mounting of strain gauges with grid dimensions as large as $5 \mathrm{~mm}$. The chosen size offered both a strong signal output from the load cell deformation and a heat dissipation area large enough to allow a higher voltage excitation (10V over the entire bridge).
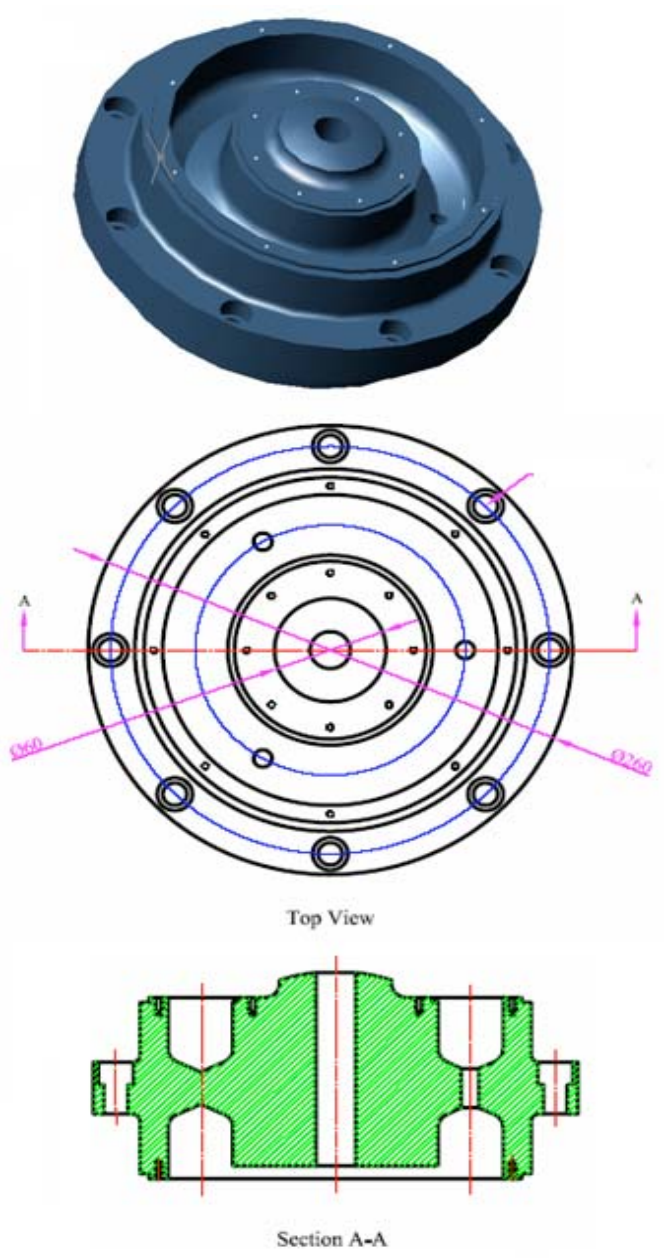

Fig. (5). Load-cell design.

Following a thorough analysis of multiple factors i.e. geometrical characteristics of the load cell, heat sink properties of the load cell material, temperature and environmental conditions in the load cell area, CEA-06-125UW-120 type strain gauges, provided by Measurements Group Inc. were chosen for the Wheatstone bridge circuit. To obtain the widest temperature range possible as well as the optimum measurement accuracy, a special bi-component adhesive MBOND 610 was used to mount the strain gauges on the load cell surfaces. Temperature curing of the assembled strain gauges was essential to provide gauge stability during elastic

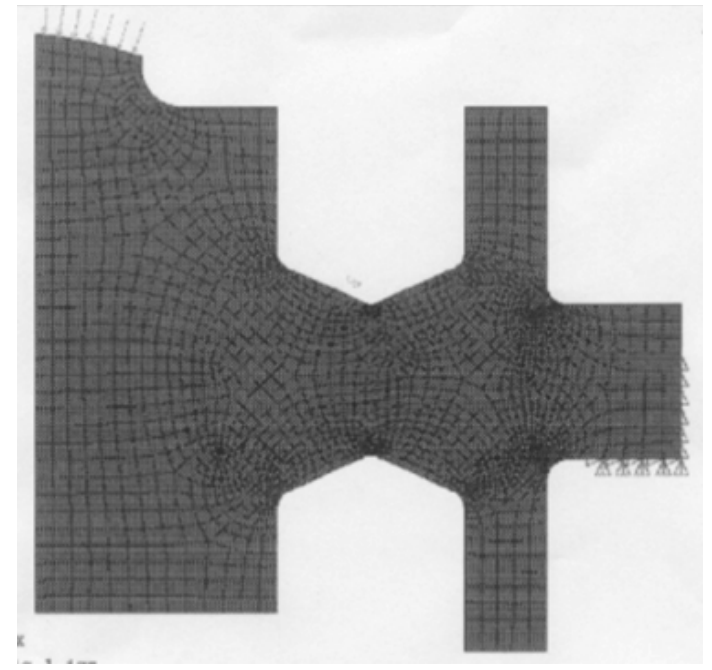

Fig. (6). Meshed axisymmetrical FE Model.

element-strain gage assembly. Uniform pressure was applied to the strain gauges during the curing process using two PTFE rings as shown in the Fig. (7). The rings were designed to match the profile of the load cell groves where the strain gauges were mounted. A force in the range, 275 $350 \mathrm{kN}$ was applied to the PTFE rings by compressing a set of 3 calibrated springs.

The position of the strain gauges is shown in Figs. ( 8 and 9) where a plot of the values of strain along the load cell surfaces is presented.

It is evident that an area of almost linear strain variation is obtained on the analysed surfaces. This feature provides an accurate and realistic variation of the strain gauges resistance with the elastic deformation of the load cell. The geometry of the surface where linear strain variation occurs allowed the mounting of strain gauges with grid dimensions as large as $5 \mathrm{~mm}$. The chosen size offered both a strong signal output from the load cell deformation and a heat dissipation area large enough to allow a higher voltage excitation (10V over the entire bridge).

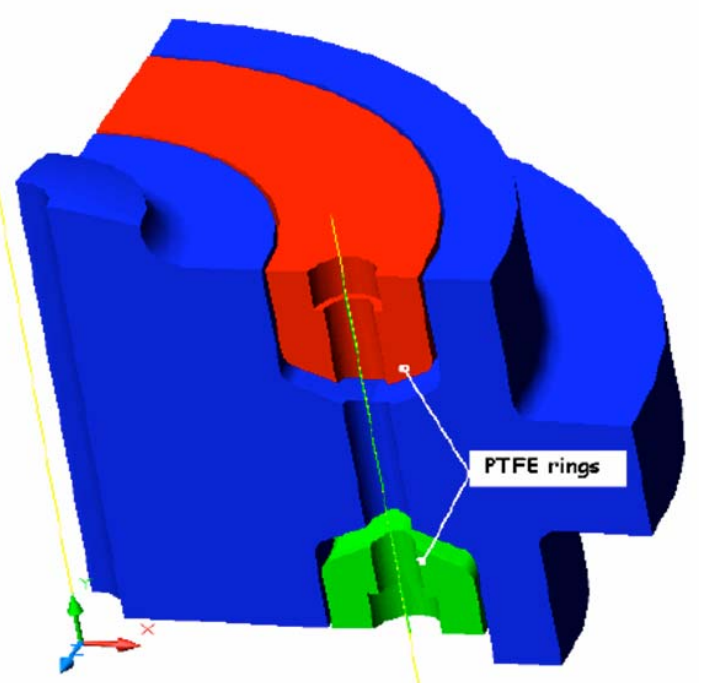

Fig. (7). PTFE pressure ring assembly design. 


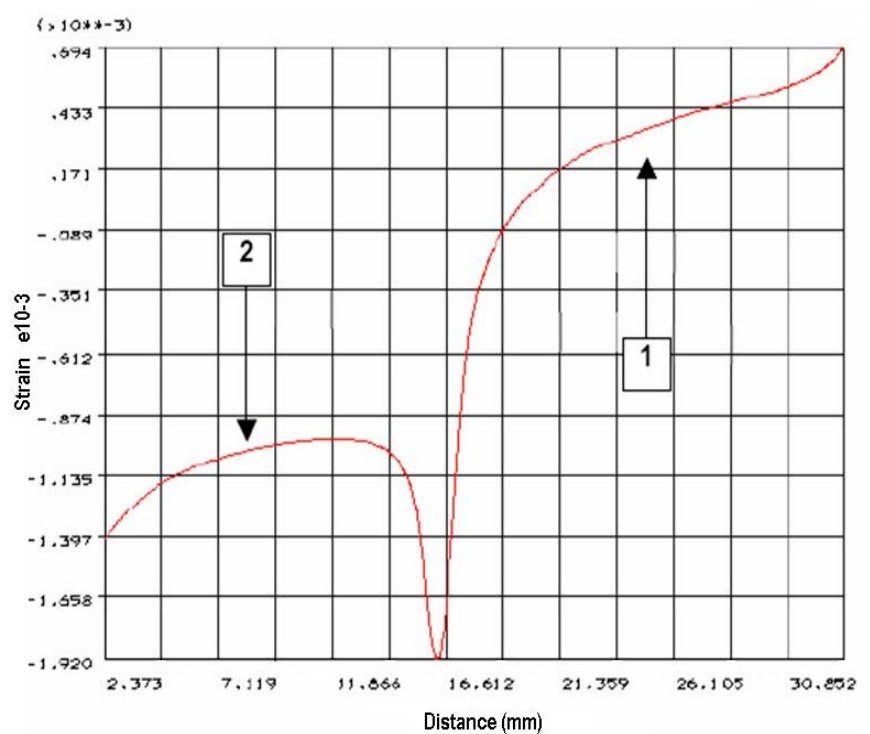

Fig. (8). Strain values and strain gauge position for upper mounting surface.

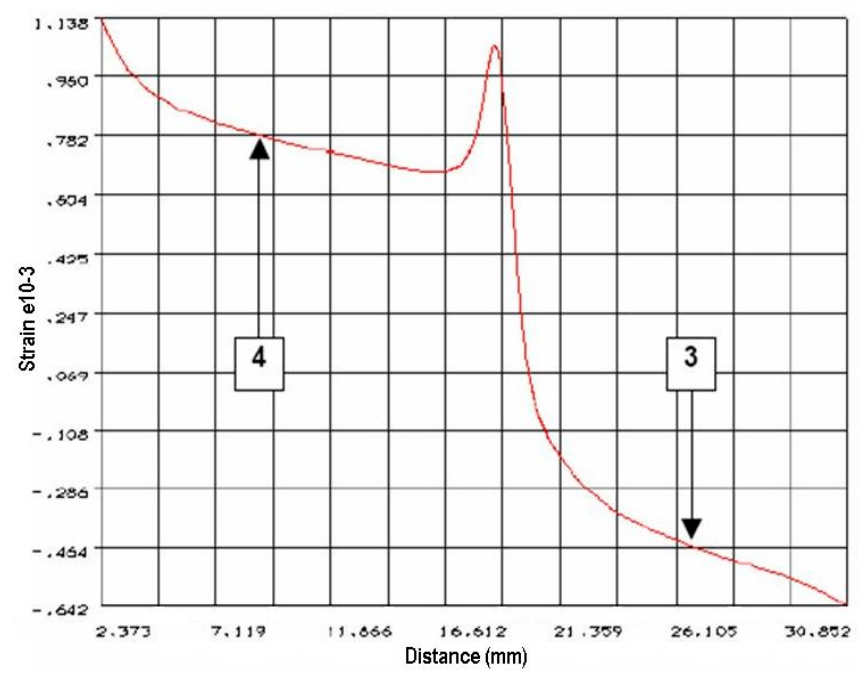

Fig. (9). Strain values and strain gauge position for lower mounting surface.

Following thermal curing and wiring of the bonded strain gages, a protective silicone rubber coating was applied over the strain gages and the soldered terminals in order to offer long-term protection against humidity and lubricant contamination during the extrusion process. The complete load cell with bonded strain gages is presented in Fig. (10). The load cell was calibrated by an accredited specialist using a known standard high precision calibration gauge. A $10 \mathrm{~V}$ excitation potential applied to the load cell bridge was provided by a highly stable DC source. The bridge output was amplified and filtered using a Signal Conditioning eXtension for Instrumentation (SCXI) 1121 signal processing module manufactured by National Instruments. Due to the low values of the response signal, a gain factor of 1000 was used to amplify the bridge output. The experimental load cell output, in millivolts, was monitored using LabVIEW software running on an IBM PC while the force measurement device attached to the calibration load cell monitored the force ap- plied to the experimental load cell. The voltage output of the experimental load cell was recorded for increments of 100 $\mathrm{kN}$ from 110 to $1500 \mathrm{kN}$.

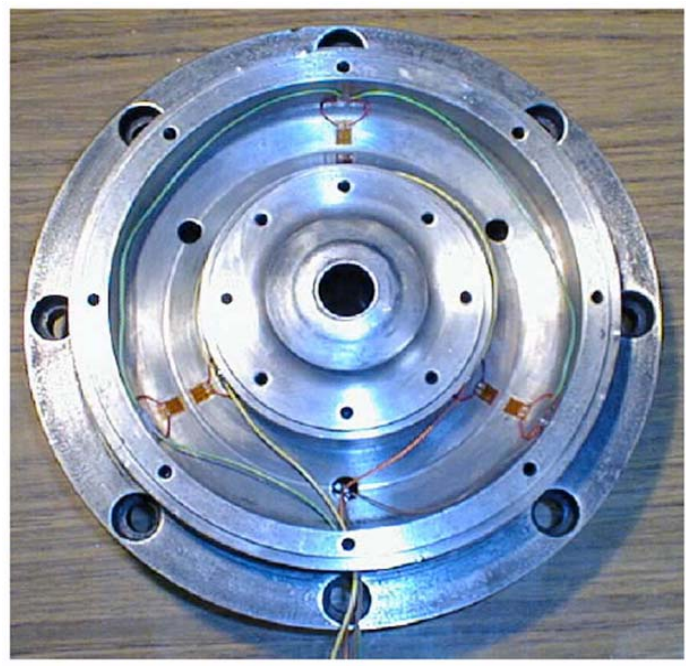

Fig. (10). Load cell with bonded gages (top view).

The curves obtained as a result of the calibration measurements show a good linearity of the force-voltage output for the load cell as shown in Fig. (11). For repeatability and accuracy reasons, the measurements were repeated three times.

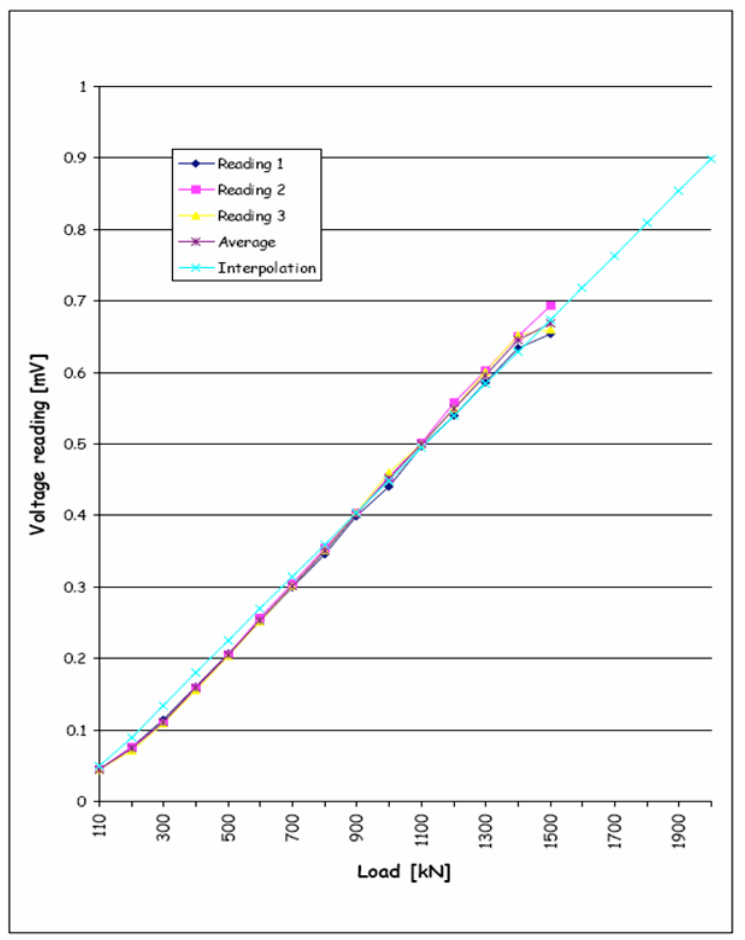

Fig. (11). Load cell calibration data.

\section{DISPLACEMENT TRANSDUCER}

In order to correlate the force data with punch travel, an LVDT transducer was attached between the top plate and the active plate of the extrusion die. The excitation was provided by the same DC source as for the load cell and the output 
signal was amplified, filtered and processed by the SCXI 1121 board used for the force signal processing. The LVDT was calibrated by correlating the voltage output with the LVDT rod displacement. The LVDT voltage output was recorded at increments of $5 \mathrm{~mm}$ in the range of 0 to $55 \mathrm{~mm}$. A linear relationship was obtained between the LVDT/punch travel and output voltage as shown in Fig. (12). Applying the same algorithm for the load cell calibration, the calibration constant of the LVDT was found as $5.6 \mathrm{~mm} / \mathrm{V}$.

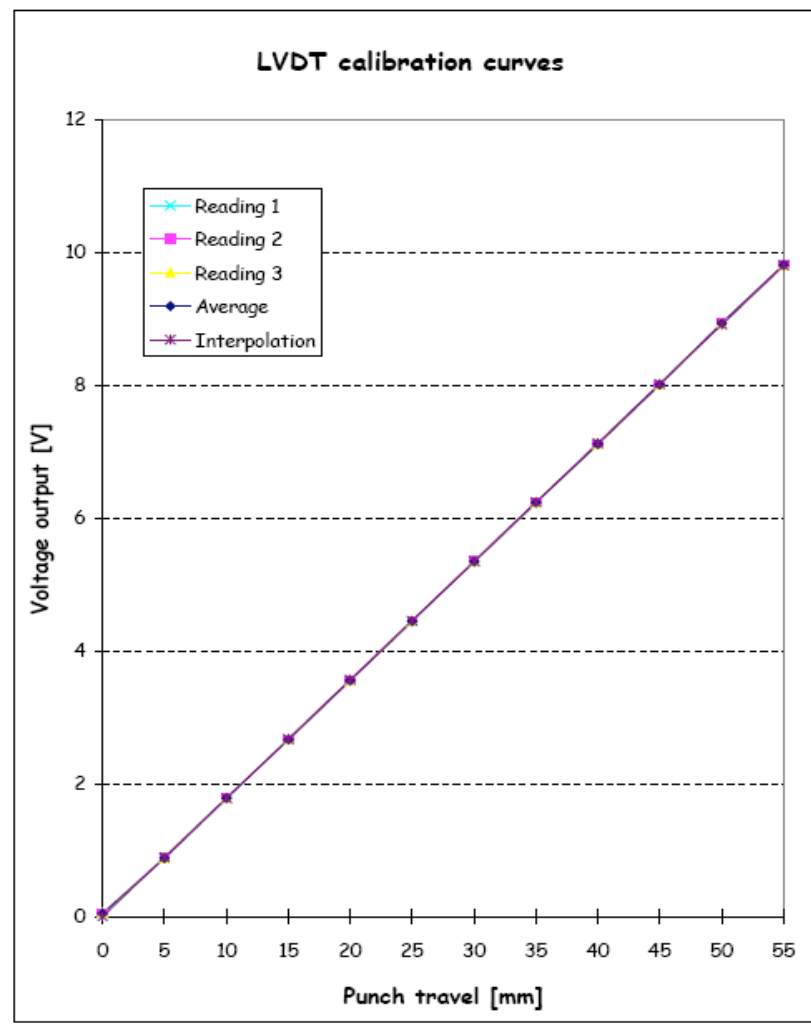

Fig. (12). LVDT calibration data.

\section{DATA ACQUISITION SYSTEM}

The signal output from both the load cell and LVDT were captured, amplified and filtered using National Instruments SCXI and I/O hardware. The signal was processed using the data acquisition and signal processing software, LabVIEW in accordance with recommended standards [1719].

The data acquisition program was designed to acquire two input signals; one from the force transducer and the second from the LVDT. The user interface for the data acquisition system is presented in Fig. (13). The LabVIEW code for this program is shown in Fig. (14). For ease of use, both signals were acquired at a scan frequency of 1000 scans/second. For one complete cycle of testing 10000 scans per channel were available, therefore the data acquisition module covered 10 seconds scan period after being triggered.

Using the front panel, the acquired signals of force and punch travel were displayed both separately (force and punch travel respectively versus number of scans) and combined (force versus punch travel) as shown in Fig. (11). At the beginning of each scan the VI program performed scale

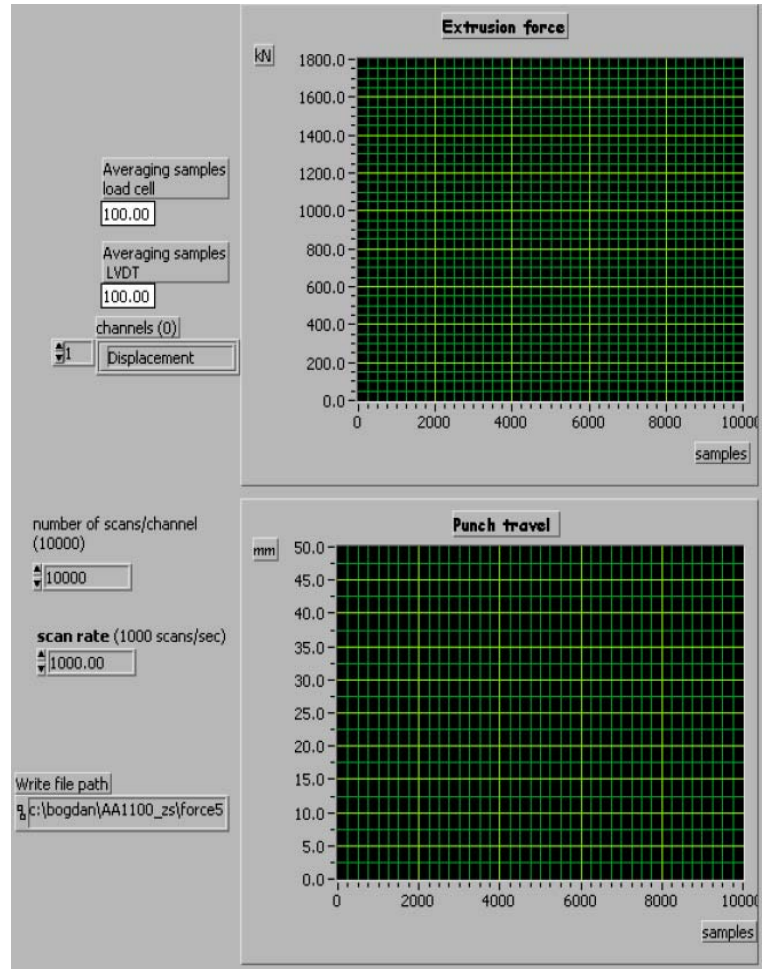

Fig. (13). LabVIEW user interface for data acquisition.

realignment. This realignment had the purpose of providing better measurement accuracy by eliminating the hysteresis of the measurement system. The realignment consisted of deducting the average value of a batch of 100 readings taken at the beginning of the process from the 1000 scans acquired on each channel. The acquired data was multiplied by the calibration constants so that it could be displayed and recorded in the appropriate unit of measurement i.e. $\mathrm{mm}$ for the punch travel and $\mathrm{kN}$ for the extrusion force readings. The punch travel and force data was recorded in text files for each experiment and used for further analysis.

\section{EXPERIMENTAL PROGRAMME}

A complete experimental program was undertaken with the extrusion tool using A1100 aluminium alloy. The chemical composition and mechanical characteristics of the billet material are presented in Tables $\mathbf{1}$ and $\mathbf{2}$ respectively. Three critical die geometry parameters were varied during the experimental work, namely the die exit diameter, $d$, die land height, $h$ and die angle, $\gamma$. This experimental programme consisted of 15 experiments with various dies. A billet of $38 \mathrm{~mm}$ diameter and $20 \mathrm{~mm}$ in height was used in all the experiments. The experimental programme as outlined below in Table $\mathbf{3}$ was repeated for two different lubricant types. Lubricant A consisted of a zinc stearate solution while Lubricant $\mathrm{B}$ was a $\mathrm{Cu}-\mathrm{Pb}$ based grease. The theoretical extrusion force, $F$ was calculated using a widely used modified upper bound equation, i.e. Eq. (1) [20].

$$
F=2 k_{f}\left[4 \mu\left(\frac{H}{D}+\frac{h}{d}\right)+\left(\frac{\mu}{\operatorname{Sin} \alpha}+1\right) \ln \frac{D^{2}}{d^{2}}\right] \frac{\pi D^{2}}{4}
$$

where: 


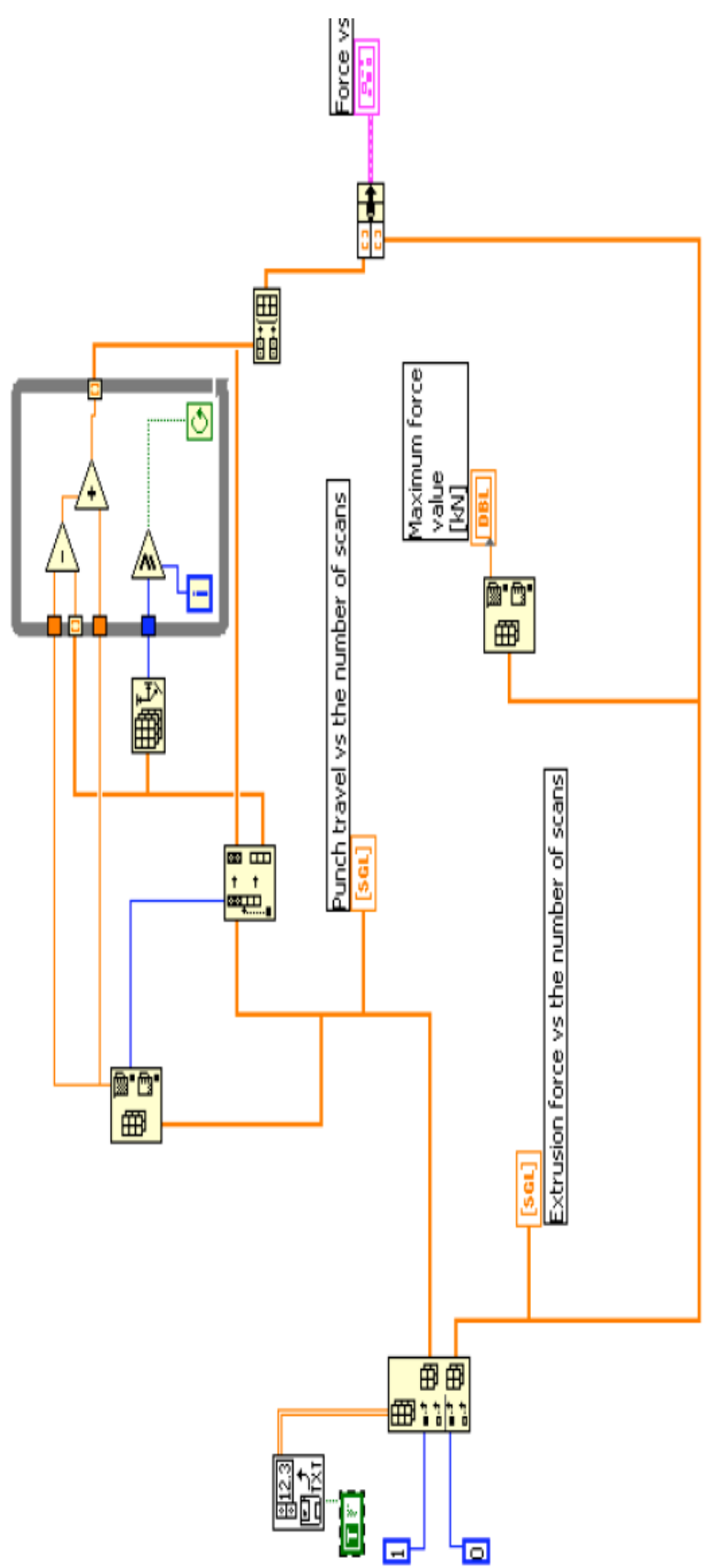

Fig. (14). LabVIEW code for data acquisition program.

$\mu=$ Coefficient of friction at die/billet interface

$D=$ Billet diameter, $(\mathrm{mm})$

$d=$ Die land diameter, $(\mathrm{mm})$

$h=$ Die land height, $(\mathrm{mm})$

$\alpha=$ Die half angle, $($ deg $)$

$H=$ Billet height, $(\mathrm{mm})$

$k_{f}=$ Maximum tangential stress at die-billet interface,

$\left(\mathrm{N} / \mathrm{mm}^{2}\right)$

The extrusion load data obtained from the load cell was recorded and compared to values determined theoretically by
Table 1. Chemical Composition of Billet Material

\begin{tabular}{|c|c|c|c|c|c|c|c|}
\hline \multicolumn{7}{|c|}{ Composition (wt\%) } \\
\hline \hline $\mathrm{Fe}$ & $\mathrm{Cu}$ & $\mathrm{Mn}$ & $\mathrm{Mg}$ & $\mathrm{Cr}$ & $\mathrm{Ni}$ & $\mathrm{Zn}$ & $\mathrm{Al}$ min \\
\hline .19 & .008 & .02 & .058 & .006 & .001 & .001 & 99.71 \\
\hline
\end{tabular}

Table 2. Mechanical Properties of Billet Material

\begin{tabular}{|c|c|c|c|}
\hline $\begin{array}{c}\text { Young's } \\
\text { Mod. }\end{array}$ & Poisson's Ratio & $\begin{array}{c}\text { Shear } \\
\text { Mod }\end{array}$ & Yield Strength \\
\hline \hline $69 \mathrm{GPa}$ & 0.33 & $26 \mathrm{GPa}$ & $34 \mathrm{MPa}$ \\
\hline
\end{tabular}

Table 3. Experimental Programme

\begin{tabular}{|c|c|c|c|}
\hline Exp. No. & $\mathbf{d}(\mathbf{m m})$ & $\mathbf{h}(\mathbf{m m})$ & $\boldsymbol{\gamma}\left({ }^{\circ}\right)$ \\
\hline \hline 1 & 9 & 2.8 & 132 \\
\hline 2 & 21 & 2.8 & 132 \\
\hline 3 & 9 & 5.2 & 132 \\
\hline 4 & 21 & 5.2 & 132 \\
\hline 5 & 9 & 2.8 & 168 \\
\hline 6 & 21 & 5.2 & 168 \\
\hline 7 & 9 & 5.2 & 168 \\
\hline 8 & 21 & 4 & 168 \\
\hline 9 & 5 & 4 & 150 \\
\hline 10 & 25 & 2 & 150 \\
\hline 11 & 15 & 6 & 150 \\
\hline 12 & 15 & 4 & 150 \\
\hline 13 & 15 & 4 & 120 \\
\hline 14 & 15 & 4 & 180 \\
\hline 15 & 15 & 4 & 150 \\
\hline
\end{tabular}

Eq. (1). The correlation between both data sets was determined graphically. Each experiment number represents different die conditions such as die semi angle, land length and percentage reduction.

\section{RESULTS}

The magnitude of the extrusion force acquired from the load cell was compared to values obtained by calculation using Equation 1. This comparison is presented in Tables 4 and 5 for lubricants $A$ and $B$ respectively. The results are shown graphically in Figs. (15 and 16).

The coefficient of friction for the Lubricant A and B was established as 0.23 and 0.25 respectively.

The data recorded was viewed using the "Read file.vi" presented in Fig. (17). The graphical user interface was also 
Table 4. Extrusion Force for Lubricant A

\begin{tabular}{|c|c|c|c|}
\hline \multirow{2}{*}{$\begin{array}{l}\text { Exp. } \\
\text { No. }\end{array}$} & \multicolumn{3}{|c|}{$\begin{array}{c}\text { Extrusion Force }(\mathrm{kN}) \\
\text { Lubricant A }\end{array}$} \\
\hline & Calculated & Experimental & \%Error \\
\hline 1 & 856.41 & 1016.01 & -15.7 \\
\hline 2 & 425.49 & 323.24 & 31.6 \\
\hline 3 & 876.38 & 961.57 & -8.9 \\
\hline 4 & 430.49 & 323.24 & 33.2 \\
\hline 5 & 826.86 & 977.87 & -15.4 \\
\hline 6 & 406.8 & 358.55 & 13.5 \\
\hline 7 & 830.89 & 945.24 & -12.1 \\
\hline 8 & 451.84 & 361.27 & 25.1 \\
\hline 9 & 1186.2 & 1260.27 & -5.9 \\
\hline 10 & 330.55 & 228.17 & 44.9 \\
\hline 11 & 575.13 & 509.95 & 12.8 \\
\hline 12 & 595.84 & 526.96 & 13.1 \\
\hline 13 & 597.08 & 492.08 & 21.3 \\
\hline 14 & 563.88 & 532.78 & 5.8 \\
\hline 15 & 586.4 & 521.37 & 12.5 \\
\hline
\end{tabular}

Table 5. Extrusion force for Lubricant B

\begin{tabular}{|c|c|c|c|}
\hline \multirow{2}{*}{$\begin{array}{c}\text { Exp. } \\
\text { No. }\end{array}$} & \multicolumn{3}{|c|}{$\begin{array}{c}\text { Extrusion Force (kN) } \\
\text { Lubricant B }\end{array}$} \\
\cline { 2 - 4 } & Calculated & Experimental & \%Error \\
\hline \hline $\mathbf{1}$ & 851.6 & 994.17 & -14.3 \\
\hline $\mathbf{2}$ & 407.1 & 331.63 & 22.8 \\
\hline $\mathbf{3}$ & 905.3 & 975.32 & -7.2 \\
\hline $\mathbf{4}$ & 430.1 & 309.66 & 38.9 \\
\hline $\mathbf{5}$ & 825.7 & 947.99 & -12.9 \\
\hline $\mathbf{6}$ & 401.3 & 321.37 & 24.9 \\
\hline $\mathbf{7}$ & 879.3 & 827.2 & 6.3 \\
\hline $\mathbf{8}$ & 424.3 & 317.78 & 33.5 \\
\hline $\mathbf{9}$ & 1226 & 1164.71 & 5.3 \\
\hline $\mathbf{1 0}$ & 320.4 & 220.02 & 45.6 \\
\hline $\mathbf{1 1}$ & 548.4 & 518.82 & 5.7 \\
\hline $\mathbf{1 2}$ & 602.1 & 553.88 & 8.7 \\
\hline $\mathbf{1 3}$ & 612.2 & 632.9 & -3.3 \\
\hline $\mathbf{1 4}$ & 571.8 & 495.4 & 15.4 \\
\hline $\mathbf{1 5}$ & 575.2 & 488.72 & 17.7 \\
\hline
\end{tabular}

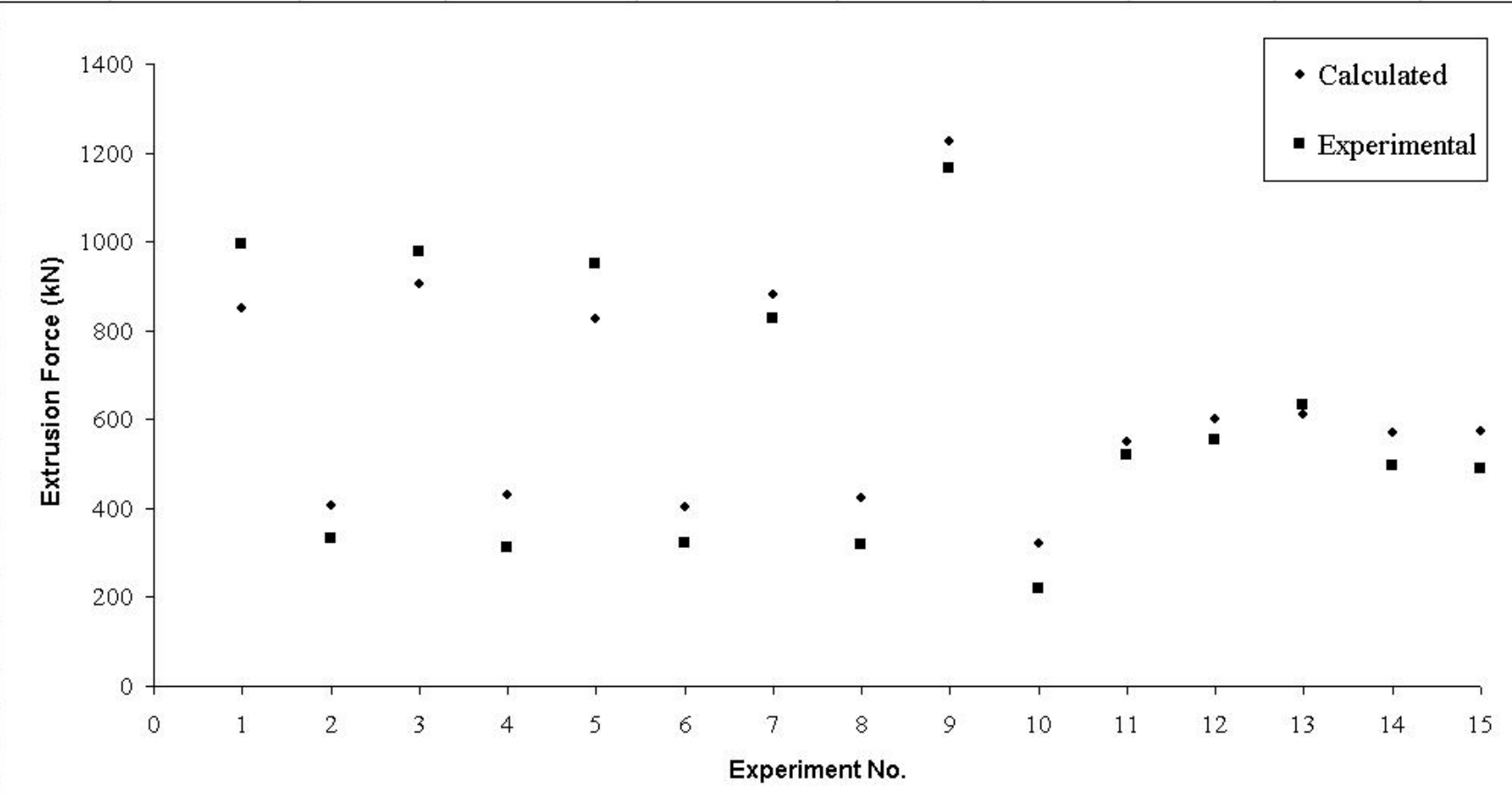

Fig. (15). Extrusion force using lubricant A.

used to provide information regarding the maximum value of the extrusion force and the punch travel.

Samples of the extruded billets are presented in Fig. (18). These samples correspond to die exit diameters of 9, 15, 21 and $25 \mathrm{~mm}$.

\section{CONCLUSIONS}

A successful experimental programme of cold extrusion of high-grade (AA1100) aluminium was carried out with purpose-built tooling. Extrusion forces were successfully determined by incorporation of a load cell in the tooling set- 


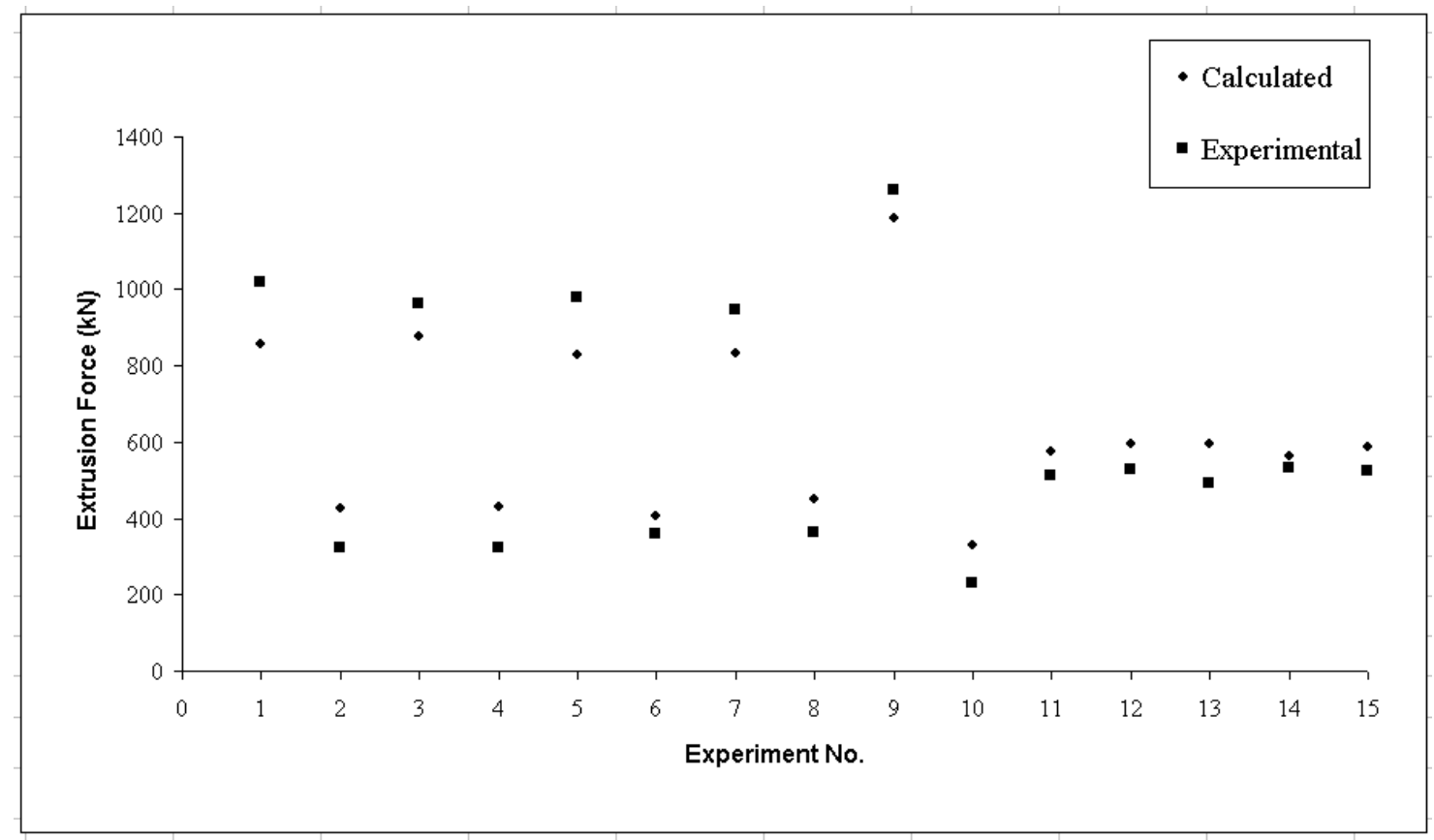

Fig. (16). Extrusion force using lubricant B.

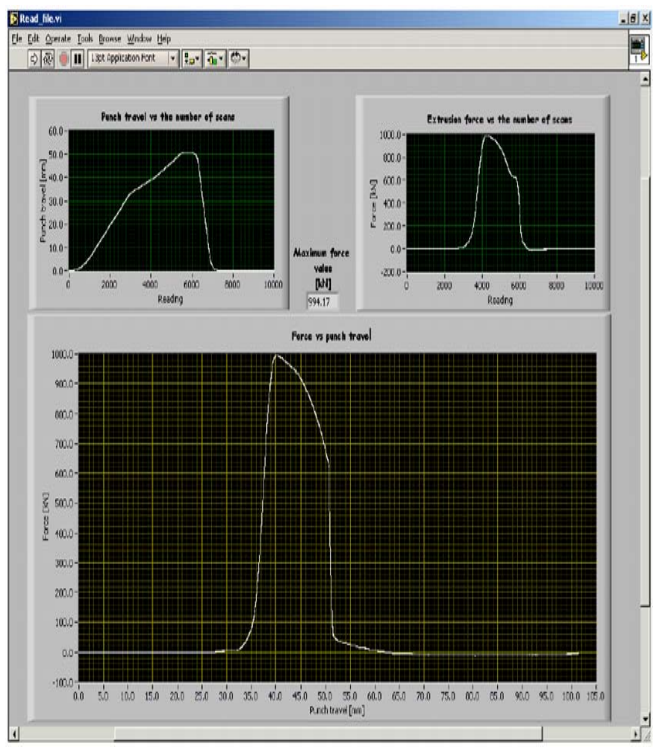

Fig. (17). Actual test data presented on LabVIEW user interface.

up. Experiments were conducted using two different lubricants; zinc stearate and an oil-based lubricant that contained high pressure lead and copper additives. There was no remarkable difference recorded in the extrusion forces required for the different lubricants. Furthermore extrusion force data obtained by calculation show reasonable agreement with data obtained by experiment, i.e. the purpose built load cell. The largest extrusion force obtained by experiment was $1260.27 \mathrm{kN}$. This force was measured when extruding the aluminium billet using a die with exit diameter, die angle, and land height of $5 \mathrm{~mm}, 150^{\circ}$ and $4 \mathrm{~mm}$ respectively. This represents a reduction in area of the billet of $98.2 \%$. The corresponding load determined by calculation was $1186.2 \mathrm{kN}$. Considerable economic savings were achieved by

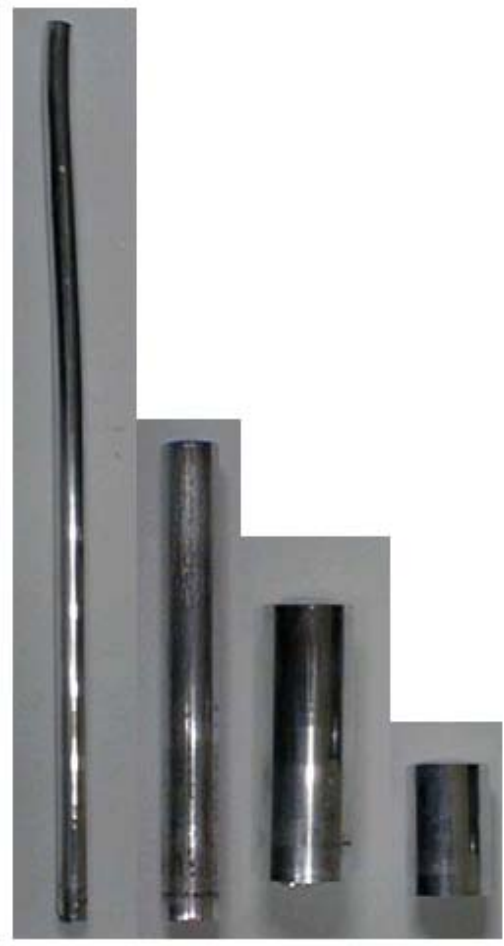

Fig. (18). Extruded samples corresponding to die exit diameters of (a) $9 \mathrm{~mm}$, (b) $15 \mathrm{~mm}$, (c) $21 \mathrm{~mm}$ and (d) $25 \mathrm{~mm}$.

designing and manufacturing the load sensing component as described in this paper. The load cell was manufactured for a total cost of 320 euros. An off-the-shelf load cell capable of measuring forces of up to $2000 \mathrm{kN}$ was priced at approximately 3,250 euros. It can be concluded that the instrumentation designed for the extrusion tool functioned correctly and can be used in future experimental programmes of forward extrusion. 


\section{REFERENCES}

[1] M. Saboori, M. Bakhshi-Jooybari, M. Noorani-Azad, and A. Gorji, "Experimental and numerical study of energy consumption in forward and backward rod extrusion", J. Mater. Proc. Technol., vol. 177, pp. 612-616, 2006

[2] H.H. Jo, H. Cho, K.W. Lee, and Y.J. Kim, "Extrudability improvement and energy consumption estimation in $\mathrm{Al}$ extrusion process of a 7003 alloy", J. Mater. Proc. Technol., vol. 130-131, pp. 407-410, 2002.

[3] B. Barisic, G. Cukor, M. Math, "Estimate of consumed energy at backward extrusion process by means of modeling approach", $J$. Mater. Proc. Technol., vol. 153-154, pp. 907-912, 2004.

[4] M. Bakhshi-Jooybari, "A theoretical and experimental study of friction in metal forming by the use of forward extrusion process", J. Mater. Proc. Technol., vol. 125-126, pp. 369-374, 2002.

[5] A. Perrot, C. Lanos, P. Estellé, Y. Melinge, "Ram extrusion force for a frictional plastic material: model prediction and application to cement paste", Rheol. Acta, vol. 45, pp. 457-467, 2006.

[6] J. Duflou, Y. Tunc,kol, A. Szekeres, P. Vanherck. "Experimental study on force measurements for single point incremental forming”, J. Mater. Proc. Technol., vol. 189, pp. 65-72, 2007.

[7] A.G. Hannsen, T. Auestad, M. Langseth and T. Tryland, "Development of a 3-component load cell for structural impact testing", Int. J. Mech. Mater. Design, vol. 2, pp. 15-22, 2005.

[8] T. Fayfield, V. Scott, W.P. Robbins, S. Ramalingam. B. Klamacki. and M. Li, "Piezoelectric thin film sires sensors for metal forming operations", in Ultrasonics Symposium, 1989, pp. 1191- 1195.
[9] V. Depierre, "Experimental measurement of forces during extrusion and correlation with theory", J. Eng. Ind., Trans. ASME, pp. 398-405, 1970.

[10] G.W. Rowe, Ed., Principles of Industrial Metalworking Processes, London, Arnold, 1977.

[11] T. Altan, S. Kobayashi, "A numerical method for estimating the temperature distribution in extrusion through conical dies", J. Eng. Ind., vol. 90, p. 107, 1968.

[12] P.K. Saha, and R.K. Gosh, "Temperature distribution during hot extrusion of aluminium - theoretical evaluation", Indian J. Technol., vol. 17, pp. 88-96, 1979.

[13] A.F. Castle and T. Sheppard, "Hot working theory applied to extrusion of some aluminium alloys", Metals Technol., vol. 3, no. 10, p. 42, 1976.

[14] P.K. Saha, "Thermodynamics and Tribology in Aluminium Extrusion", Wear, vol. 218, pp. 179-190, 1998.

[15] T.J. Ward, R.M. Kelly, G.A. Jones, and J.F Heffron, "The effects of Nitrogen - liquid and gaseous - on aluminium extrusion productivity", J. Met., p. 28, 1984.

[16] GEP. Box, and NR. Draper, Empirical Model-Building and Response Surfaces, Wiley, New York, 1987.

[17] B. Mihura, LabVIEW for Data Acquisition, Prentice Hall, 2001.

[18] M.L. Chugani, R.A. Somont, M. Cerna, LabVIEW Signal Processing, Prentice Hall, 1998.

[19] J. Conway, A Software Engineering approach to LabVIEW, Prentice Hall, 2003.

[20] I. Tapalaga, Gh. Achimas, H. Iancau, D. Banabic, A. Coldea, "Cold Extrusion of Metals", in Metal Forming conference, Dacia, ClujNapoca, Romania, 1986.

(C) Tiernan and Draganescu; Licensee Bentham Open.

This is an open access article licensed under the terms of the Creative Commons Attribution Non-Commercial License (http://creativecommons.org/licenses/by-nc/3.0/) which permits unrestricted, non-commercial use, distribution and reproduction in any medium, provided the work is properly cited. 